\title{
Iron homeostasis in a mouse model of thalassemia intermedia is altered between adolescence and adulthood
}

\author{
Chanita Sanyear ${ }^{\text {Equal first author, }{ }^{1} \text {, Punnee Butthep }}{ }^{1}$, Wiraya Eamsaard ${ }^{2}$, Suthat Fucharoen ${ }^{3}$, Saovaros Svasti ${ }^{3}$, \\ Patarabutr Masaratana ${ }^{\text {Corresp. Equal first author, } 2}$ \\ ${ }^{1}$ Department of Pathology, Faculty of Medicine, Ramathibodi Hospital, Mahidol University, Bangkok, Thailand \\ 2 Department of Biochemistry, Faculty of Medicine Siriraj Hospital, Mahidol University, Bangkok, Thailand \\ 3 Thalassemia Research Center, Institute of Molecular Biosciences, Mahidol University, Bangkok, Thailand \\ Corresponding Author: Patarabutr Masaratana \\ Email address: patarabutr.mas@mahidol.ac.th
}

Background. Iron overload is one of common complications of $\beta$-thalassemia. Systemic iron homeostasis is regulated by iron- regulatory hormone, hepcidin, which inhibits intestinal iron absorption and iron recycling by reticuloendothelial system. In addition, body iron status and requirement can be altered with age. In adolescence, iron requirement is increased due to blood volume expansion and growth spurt. Heterozygous $\beta$-globin knockout mice $\left(H b b^{\text {th3/+ }} ; \mathrm{BKO}\right)$ is a mouse model of thalassemia widely used to study iron homeostasis under this pathological condition. However, effects of age on iron homeostasis, particularly the expression of genes involved in hemoglobin metabolism as well as erythroid regulators in the spleen, during adolescence have not been explored in this mouse model. Methods. Iron parameters as well as the mRNA expression of hepcidin and genes involved in iron transport and metabolism in wildtype (WT) and BKO mice during adolescence (6-7 weeks old) and adulthood (16-20 weeks old) were analyzed and compared by 2 -way ANOVA. Results. The transition of adolescence to adulthood was associated with reductions in duodenal iron transporter mRNA expression and serum iron levels of both WT and BKO mice. Erythrocyte parameters in BKO mice remained abnormal in both age groups despite persistent induction of genes involved in hemoglobin metabolism in the spleen and progressively increased extramedullary erythropiesis. In BKO mice, adulthood was associated with increased liver hepcidin and ferroportin mRNA expression along with splenic erythroferrone mRNA suppression compared to adolescence. Conclusion. Our results demonstrated that iron homeostasis in a mouse model of thalassemia intermedia was altered between adolescence and adulthood. The present study underscores the importance of the age of thalassemic mice in the study of molecular or pathophysiological changes under thalassemic condition. 


\section{Iron homeostasis in a mouse model of thalassemia}

\section{2 intermedia is altered between adolescence and}

\section{3 adulthood}

4

5

6 Chanita Sanyear ${ }^{1,2}$, Punnee Butthep ${ }^{1}$, Wiraya Eamsaard ${ }^{4}$, Suthat Fucharoen ${ }^{2}$, Saovaros Svasti ${ }^{2,3}$,

7 Patarabutr Masaratana ${ }^{4}$

8

$9{ }^{1}$ Department of Pathology, Faculty of Medicine, Ramathibodi Hospital, Mahidol University,

10 Thailand

112 Thalassemia Research Center, Institute of Molecular Biosciences, Mahidol University,

12 Thailand

$13{ }^{3}$ Department of Biochemistry, Faculty of Science, Mahidol University, Thailand

$14{ }^{4}$ Department of Biochemistry, Faculty of Medicine Siriraj Hospital, Mahidol University,

15 Thailand

16

17 Corresponding Author:

18 Patarabutr Masaratana, M.D. Ph.D.

19

20

21

22
Department of Biochemistry, Faculty of Medicine Siriraj Hospital

2 Prannok Road, Siriraj, Bangkoknoi, Bangkok 10700, Thailand

Email address: patarabutr.mas@mahidol.ac.th 


\section{Abstract}

24 Background. Iron overload is one of common complications of $\beta$-thalassemia. Systemic iron

25 homeostasis is regulated by iron- regulatory hormone, hepcidin, which inhibits intestinal iron 26 absorption and iron recycling by reticuloendothelial system. In addition, body iron status and 27 requirement can be altered with age. In adolescence, iron requirement is increased due to blood 28 volume expansion and growth spurt. Heterozygous $\beta$-globin knockout mice $\left(H b b^{\text {th } 3 /+} ; \mathrm{BKO}\right)$ is a 29 mouse model of thalassemia widely used to study iron homeostasis under this pathological condition. However, effects of age on iron homeostasis, particularly the expression of genes involved in hemoglobin metabolism as well as erythroid regulators in the spleen, during

32 adolescence have not been explored in this mouse model.

33 Methods. Iron parameters as well as the mRNA expression of hepcidin and genes involved in 34 iron transport and metabolism in wildtype (WT) and BKO mice during adolescence (6-7 weeks 35 old) and adulthood (16-20 weeks old) were analyzed and compared by 2-way ANOVA.

36 Results. The transition of adolescence to adulthood was associated with reductions in duodenal 37 iron transporter mRNA expression and serum iron levels of both WT and BKO mice.

38 Erythrocyte parameters in BKO mice remained abnormal in both age groups despite persistent 39 induction of genes involved in hemoglobin metabolism in the spleen and progressively increased extramedullary erythropiesis. In BKO mice, adulthood was associated with increased liver hepcidin and ferroportin mRNA expression along with splenic erythroferrone mRNA suppression compared to adolescence.

43 Conclusion. Our results demonstrated that iron homeostasis in a mouse model of thalassemia 44 intermedia was altered between adolescence and adulthood. The present study underscores the importance of the age of thalassemic mice in the study of molecular or pathophysiological changes under thalassemic condition.

47

Keywords Heterozygous $\beta$-globin knockout mice, hepcidin, age, thalassemia, iron transporters 49 


\section{Introduction}

51

52 53

54

55

56

57

58

59

60

61

62

63

64

65

66

67

68

69

70

71

72

73

74

75

76

77

78

79

80

Iron, one of essential trace elements, is involved in several biological processes such as oxidative phosphorylation and hemoglobin synthesis (Jandl et al., 1959; Pollycove \& Mortimer, 1961; Hentze et al., 2004). Iron is transported in the plasma by apotransferrin protein.

Transferrin-bound iron is taken up into cells by transferrin receptor 1 (TfR1) for cellular storage or utilization. In erythroid cells, the acquired iron is used for the production of hemoglobin which involves several proteins including mitoferrin 1 (Mfrn1), a mitochondrial iron transporter, and 5-aminolevulinic acid synthase 2 (ALAS2), an enzyme catalyzing the first reaction of erythroid heme biosynthetic pathway (Shaw et al., 2006; Paradkar et al., 2009; Amigo et al., 2011; Lane et al., 2015). Reticuloendothelial (RE) cells are responsible for the reutilization of iron in hemoglobin of senescent red blood cells. Upon erythrophagocytosis of senescent erythrocytes by RE cells, hemoglobin is degraded by heme oxygenase-1 (HO-1) and iron is released into the circulation for reutilization. This RE iron recycling process accounts for the majority of iron in the plasma. The minority of plasma iron is acquired from intestinal iron absorption (Kong et al., 2014; Wallace, 2016).

Several molecules are involved in the absorption of iron. Firstly, dietary iron $\left(\mathrm{Fe}^{3+}\right)$ is reduced by duodenal cytochrome b (Dcytb) located at the apical membrane of enterocytes (McKie et al., 2001). The resultant ferrous is taken up into enterocytes by divalent metal transporter 1 (DMT1) (Gunshin et al., 1997) and then transferred into the circulation by an iron efflux protein, ferroportin (McKie et al., 2000; Donavan et al., 2000; Abboud \& Haile, 2000).

The ferrous is subsequently oxidized by hephaestin into ferric which is then transported along the plasma by apotransferrin (Vulpe et al., 1999). Ferroportin not only involves in cellular export of dietary iron but also facilitates iron efflux from splenic macrophages and hepatocytes. In addition to intestinal iron uptake, DMT1 is also involved in the transport of transferrin-bound iron from endosome into cytoplasm.

Cellular iron homeostasis is regulated by iron responsive elements (IRE), which are located at either 5' or 3' untranslated region of several mRNAs encoding proteins related to cellular iron metabolism including TfR1, DMT1, ferroportin and ALAS2 (Koeller et al., 1989; Cox et al., 1991; Dandekar et al., 1991; Abboud \& Haile, 2000; McKie et al., 2000; Hubert \& Hentze, 2002). The expression of these proteins is post-transcriptionally controlled in response to cellular iron levels through the interaction between IRE and iron regulatory protein (IRP). 
81 TfR1 and DMT1 expression is increased under iron depletion state and vice versa under iron

82 repletion. On the other hand, the expression of ferroportin and ALAS2 is suppressed in response 83 to iron deficiency and enhanced during iron loading.

84 Systemic iron homeostasis is regulated by hepcidin, the liver-secreted iron regulatory 85 hormone, which binds ferroportin and induces its internalization and degradation (Nemeth et al., 86 2004). Consequently, intestinal iron absorption and RE iron recycling is inhibited resulting in 87 reduced serum iron levels. The expression of hepcidin is influenced by several factors. Body 88 iron status and inflammation have been shown induce hepcidin expression whereas 89 erythropoietic iron demand and hypoxia are hepcidin suppressors (Pigeon et al., 2001; Nicolas et al., 2002a; Nicolas et al., 2002b). Bone morphogenetic protein 6 (Bmp6) has been shown to play a crucial role in hepcidin induction in response to iron stores (Andriopoulos et al., 2009). In addition to the aforementioned factors, ineffective erythropoiesis can also suppress the expression of hepcidin. Growth differentiation factor 15 (Gdf15), twisted gastrulation 1 (Twsg1) and erythroferrone (Erfe) which are produced by erythroid precursors have been proposed to be potential candidates for hepcidin regulator under such conditions including thalassemia (Tanno et al., 2007; Tanno et al., 2009; Kautz et al., 2014).

Thalassemia is a hematological disease caused by mutations of globin-encoding genes or their promoters leading to decreased production of the respective globin chains. In $\beta$ thalassemia, the production of $\beta$-globin is reduced or absent leading to the accumulation of unmatched $\alpha$-globin, erythroid cell death, ineffective erythropoiesis and, subsequently, anemia. Furthermore, systemic iron overload occurs as a result of increased intestinal iron absorption and/or regular blood transfusion with inadequate iron chelation (Weatherall \& Clegg, 2001; Higgs et al., 2012). Animal models especially mouse (Mus Musculus) is a model that most widely used to study the pathophysiological changes or treatment of human disease (Capecchi, 2005). Heterozygous $\beta$-globin knockout mice ( $\mathrm{Hbb}^{\text {th3/+}}$; BKO), one of commonly utilized thalassemia mouse model, were generated by heterozygous deletion of both murine $\beta$-globin genes (Hbb-b1 and Hbb-b2) (Detloff et al., 1994; Yang et al., 1995). Phenotypic characterization of this mouse model includes mild-to-moderate anemia, growth retardation, ineffective erythropoiesis, extramedullary erythropoiesis and parenchymal iron loading in several tissues

110 such as liver, spleen and heart which resemble clinical features of thalassemia in human (Yang et 111 al., 1995). 
Several factors including age, gender and strain have been shown to influence iron

113 parameters as well as the expression of hepcidin and other iron regulatory genes (Ahluwalia et

114 al.,2000; Courselaud et al., 2004; Krijt et al., 2004; Weizer-Stern et al., 2006; Hahn et al., 2009;

115 McLachlan et al., 2017). Previous study reported that iron levels in various tissues were

116 generally higher in aged mice than younger adult mice (Hahn et al., 2009). The expression of

117 genes involved in iron metabolism was proposed to be dynamic as a result of age and iron stores

118 (De Franceschi et al., 2006). Additionally, previous study proposed that age must be considered

119 in the studies of iron metabolism (Chen et al., 2009). It is noteworthy that mice at different ages

120 might have distinctive responses to alterations in iron metabolism. Indeed, the study in $\beta$ -

121 thalassemia mouse model $\left(H b b^{\text {th } 3 /^{+}}\right)$aged 2, 5 and 12 months demonstrated different systemic

122 iron regulatory responses in young adult and elderly thalassemic mice (Gardenghi et al., 2007).

123 Although BKO mice have been widely used as an animal model in thalassemia research, little is

124 known whether the expression of hepcidin along with major iron transporters in these mice differ

125 across different age groups particularly in adolescence. Murine adolescent age is defined as the

126 postnatal period ranging from weaning (PND 21) to adulthood (PND 60) (Laviola et al., 2003).

127 It is also suggested that adult mice should be at least 3 months of age as most biological

128 processes and structures continue to rapidly grow or mature after the age of sexual maturation

129 (35 days) until roughly 3 months old (Flurkey et al., 2007). Moreover, iron status and iron

130 homeostasis might be altered in adolescence as a result of increased body iron requirement for

131 growth and development (Beard, 2000). Thus, the present study aims to explore the effects of

132 age on iron parameters as well as the mRNA expression of hepcidin and major iron transport

133 machineries in WT and thalassemic mouse model aged 6-7 weeks old and 16-20 weeks old,

134 which represent adolescence and adulthood, respectively.

135

136 Materials \& Methods

$137 \quad$ Animal

138 Male C57BL/6 wild type (WT) and heterozygous $\beta$-globin knockout mice $\left(H b b^{\text {th } 3 /+}\right.$;

139 BKO) at two age groups: 6-7 weeks old and 16-20 weeks old were used (5 mice per each of the

140 age group). All mice were obtained from the Thalassemia Research Center, Institute of

141 Molecular Biosciences, Mahidol University, Thailand. The mice were given rodent chow (C.P.

142 mice feed $082 \mathrm{G}$ containing $180 \mathrm{ppm}$ of iron, Perfect Companion Group, Thailand) and water $a d$ 
143 libitum. The temperature and humidity were maintained at $25 \pm 2{ }^{\circ} \mathrm{C}$ and $55 \pm 10 \%$, respectively, 144 with 12 hours light/dark cycle. The mice were sacrificed and blood samples were collected by 145 cardiac puncture. Liver, spleen and duodenum samples were snapped frozen and stored at $-80^{\circ} \mathrm{C}$. 146 Animal protocols were approved by Institute of Molecular Biosciences Animal Care and Use 147 Committee, Mahidol University, Thailand (COA.NO.MB-ACUC 2016/003).

148

\section{Measurement of hematological and iron parameters}

Hematological parameters were analyzed using an automated hematological analyzer

151

152

153

154

155

156

157

158

159

160

161

162

163

164

165

166

167

168

169

170

171

172

173

(Mindray, China). Serum iron level was determined using QuantiChrome iron assay kit

(BioAssay System, USA) according to the manufacturer's protocol. Liver and spleen non-heme iron contents were determined by a modification of the method of Foy et al. (Foy et al.,1967) as described by Simpson and Peters (Simpson \& Peters, 1990).

\section{Histopathological studies}

Liver, spleen and duodenal tissue samples were fixed in 10\% formalin buffer. The fixed tissue samples were then dehydrated, embedded in paraffin, and sectioned at 4- $\mu \mathrm{m}$ thickness. Tissue sections were stained with hematoxylin and eosin (H\&E) for morphological examination and Perl's Prussian blue for iron accumulation according to standard protocols. The stained slides were analyzed using a Nikon ECLIPSE 80i light microscope (Nikon, Japan).

The amounts of mononuclear, polymorphonuclear and hematopoietic cells in the liver were evaluated in 10 non-overlapping areas acquired by random sampling. The numbers of cells were scored using a grading criteria described by Yatmark et al. (Yatmark et al., 2014) as follows: score $0=$ absent ; score $1=$ mild $(1$ - 10 cells $)$; score $2=$ moderate $(11$ - 50 cells $)$; score 3 = severe (more than 50 cells).

For iron accumulation assessment, the whole tissue section of each mouse ( 5 mice per group) was examined and the overall extent of iron deposition in each mouse was estimated by a modification of grading system described by Barton et al. (Barton et al., 1995) and Yatmark et al. (Yatmark et al., 2014) as follows:

a) Liver iron deposition: score $0=$ no visible iron deposition; score $1=$ slight iron deposition in the cytoplasm of Kupffer cells ; score $2=$ prominent iron accumulation in Kupffer cells ; score 3 = iron deposition in hepatocytes ; score $4=$ iron deposition in hepatocytes and 
174 fibrous tissue of portal tracts or septa

175 b) Splenic iron deposition: score $0=$ no visible iron deposition ; score $1=$ indicated iron 176 deposit in marginal sinus of spleen; score 2 = densely aggregated iron deposition ; score 3,= 177 clumps of iron accumulation : score $4=$ clumps of iron aggregation with frequent iron clumps.

178 c) Duodenal iron deposition: score $0=$ no visible iron deposition; score $1=$ iron deposits 179 in the supranuclear region of enterocyte; score $2=$ densely aggregated iron deposition ; score 3 ,= 180 visible clumps of iron accumulation ; $4=$ clumps of iron aggregation with frequent iron clumps 181 182

\section{Quantitative RT-PCR}

183

184 185

186

187

188

189

190

191

192

193

194

195

196

197

198

199

200

201

202

203

204

RNA was extracted from the liver, spleen and duodenum using TRIzol reagent (Ambion, USA), and complementary DNA was synthesized using a Tetro cDNA synthesis kit (Bioline, USA) as per manufacturers' protocols. Quantitative RT-PCR was performed using the CFX96 Thermal Cycler (Bio-Rad, USA). The gene expression was normalized to $\beta$-actin (Actb) expression. The results were presented as minus delta $\mathrm{Ct}$ values $\left(\mathrm{Ct}_{\text {target }}-\mathrm{Ct}_{\mathrm{Actb}}\right)$ (Livak \& Schmittgen, 2001). The sequence of gene-specific primers is listed in Table 1.

\section{Statistical analysis}

All data were expressed as mean \pm standard error of the means (SEM). The comparison of the means across the two age groups was performed by 2-way ANOVA with Bonferroni posthoc test. A $P$-value less than 0.05 was considered significant. All statistical analyses were performed using GraphPad Prism 6 software (GraphPad Software, Inc., La Jolla, CA, USA).

\section{Results}

\section{Iron parameters, but not hematological parameters, of thalassemic mice were} affected by age

To explore whether hematological parameters were affected by the age of mice, EDTA blood samples from WT and BKO mice aged 6-7 weeks and 16-20 weeks were analyzed for complete blood count. As shown in Table 2, significant effects of phenotype on several hematological parameters were observed. BKO mice had lower hemoglobin, hematocrit, MCV and RBC count along with higher RDW than age-matched WT which corresponded with 
205 thalassemia phenotype. Furthermore, such findings remained unaltered between adolescent and 206 adult BKO mice. In WT mice, adulthood was associated with increased RBC count, 207 hemoglobin, hematocrit along with reduced MCV and RDW compared to adolescence.

208 Serum iron levels as well as non-heme iron levels in the liver and spleen were measured 209 to determine body iron status. Increased liver and spleen non-heme iron levels were observed in 210 BKO mice whereas serum iron levels did not differ from WT mice (Table 2). In both WT and 211 BKO mice, a significant reduction in serum iron levels were observed in adult mice compared to 212 adolescent mice while liver non-heme iron levels were unaltered. Interestingly, adulthood was 213 associated with a significant increase in spleen non-heme iron levels only in BKO mice.

214 Perl's Prussian blue staining revealed iron accumulation in the liver and spleen of BKO 215 mice (Fig. 1C-D, 1G-H). Notably, iron deposition was mainly confined in hepatic Kupffer cells 216 and splenic macrophages in both red and white pulps. Additionally, a weakly positive iron 217 staining was observed in the supranuclear region of duodenal enterocytes (Fig. 1K-L). The 218 degree of iron staining was relatively higher in the spleen than the liver and duodenum (Table 3). 219 In agreement with non-heme iron results, an increase in iron deposition score was found in the 220 spleen of adult BKO group compared to adolescent BKO mice whereas liver and duodenal iron 221 deposition score was unaltered between different age groups.

222

223

The extent of extramedullary hematopoiesis in thalassemic mice was progressively increased with increasing age

Microscopic examination of liver and spleen tissue samples revealed hematopoietic and mononuclear cell infiltration in the liver and spleen of BKO mice which was suggestive for the presence of extramedullary hematopoiesis (Fig. 2C-D, 2G-H). As shown in Table 4, the livers of adult BKO mice had increased number of mononuclear cell infiltration and hematopoietic cells than adolescent BKO mice suggesting that the extent of extramedullary hematopoiesis progressively increased at least during the studied age range.

Furthermore, genes involved in hemoglobin synthesis (Tfrc, Slc25a37 and Alas2) and degradation (Hmox 1) were induced in the spleen of BKO mice compared to WT mice (Fig. 3). Interestingly, mRNA levels of these genes were significantly decreased in adult WT mice compared to adolescent counterpart while the expression in BKO mice was similar between the 235 two age groups. 
237 Thalassemic mice had decreased liver hepcidin mRNA expression relative to liver non238 heme iron contents during both adolescence and adulthood

239 Quantitative RT-PCR revealed that the levels of liver hepcidin mRNA were similar 240 between WT and BKO mice during adolescence (Fig. 4A). In adulthood, hepcidin mRNA 241 expression in BKO mice was higher than adolescent mice. On the contrary, hepcidin mRNA

242 levels in WT were not affected by age. To account for liver iron overload, the mRNA expression 243 of hepcidin was corrected by liver non-heme iron contents. As shown in Fig. 4B, BKO mice in 244 both age groups had lower hepcidin mRNA levels relative to liver non-heme iron contents than 245 WT mice. No effect of age on this parameter was observed.

246 The mRNA expression of upstream hepcidin regulators in the liver and spleen was also 247 determined. Liver Bmp6 mRNA levels as well as splenic mRNA expression of Gdf15, Twsg1 248 and Erfe were higher in BKO mice compared to WT mice (Fig. 4 C-F). In general, the mRNA 249 levels of these hepcidin regulators was not altered between adolescent and adult mice except 250 splenic Erfe mRNA expression which was downregulated in adult BKO mice.

251

252

253

\section{Iron transporter mRNA expression was differentially affected by thalassemia and age}

In the liver, DMT1 mRNA expression was not affected by thalassemia and age (Fig. 5A).

254

255

256

257

258

259

260

261

262

263

264

265

266

In contrast, ferroportin mRNA levels were increased in BKO mice (Fig. 5B). A significant

ferroportin mRNA induction was observed in adult BKO mice compared to adolescent counterpart.

In addition, increased splenic mRNA levels of DMT1 and ferroportin were noted in BKO mice but the expression was not altered between adolescent and adult mice (Fig. 5 C-D).

As shown in Fig. 6, thalassemia had significant positive effects of the mRNA expression of Dytb and DMT1 in the duodenum. Furthermore, Dcytb and DMT1 mRNA levels were significantly reduced in adult WT and BKO mice compared to respective adolescent group. On the other hand, duodenal ferroportin mRNA expression was not significantly affected by phenotype or age.

\section{Discussion}


Our study reveals that iron parameters and the expression of genes involved in iron

268

269

270

271

272

273

274

275

276

277

278

279

280

281

282

283

284

285

286

287

288

289

290

291

292

293

294

295

296

homeostasis of WT and thalassemic mice differ between adolescence and adulthood. Although, previous study has determined hematological parameters and the expression of iron genes in thalassemic mice at different ages, the study focused on gene expression in the liver $(D e$ Franceschi et al., 2006). In addition, it was conducted in only in mature adult and aged mice.

The study by Gardenghi et al. utilized thalassemic mice aged 2, 5 and 12 months to compare iron status and iron homeostasis, however, the expression of splenic iron transporters as well as genes involved in hemoglobin synthesis and genes encoding erythriod regulators (Erfe, Gdf15, Twsg1) was not explored (Gardenghi et al., 2007).

In accordance with previous studies (Jamsai et al., 2005; Nai et al., 2012; Upanan et al., 2015), we observed thalassemia intermedia phenotype in BKO mice during adolescence and adulthood as characterized by microcytic anemia, extramedullary hematopoiesis as well as iron accumulation in the liver and spleen. In the present study, hematological results revealed relatively lower red blood cell count and hemoglobin levels in both WT and BKO mice than previously reported values (De Franceshi et al., 2006; Weizer-Stern et al., 2006; Gardenghi et al., 2007; Vogiatzi et al., 2010; Nai et al., 2012; Gelderman et al., 2015; Kautz et al., 2015; Li et al., 2017). However, comparable hematological parameters were also reported in 20-week old WT and BKO mice obtained from the same animal facility as our study (Wannasuphaphol et al., 2005). Furthermore, we found that adolescent WT mice had significantly lower RBC count, hemoglobin and hematocrit along with significantly higher MCV and RDW than adult WT mice. Physiological changes in hematological parameters of young mice including lower hemoglobin, lower hematocrit, higher MCV has previously been documented (Everds, 2007). In agreement with our results on RDW values, variable red blood cells morphology has also been noted in young mice (Bannerman, 1983). In contrast to WT mice, the hematological abnormalities in BKO mice persisted in both age groups indicating for the persistence of thalassemic phenotype in these mice. In addition to age-associated hematological changes, increased serum iron levels during adolescence were observed in both WT and BKO mice. A similar trend has previously been reported in normal mice and rats (Lesbordes-Brion et al., 2006; Kong et al., 2015). We speculate that serum iron levels were increased during adolescence as a result of increased iron requirement for erythropoiesis. 

the essential iron acquisition machinery of maturing erythroid cells (Kong et al., 2014; Gammella et al., 2017), while Mfrn1 and ALAS2 are required for heme biosynthesis (Hentze et al., 2004; Amigo et al., 2011; Chiabrando et al., 2014). The expression of Mfrn1 and ALAS2 is transcriptionally regulated by transcription factor GATA-1 during erythroid maturation (Amigo et al., 2011; Tanimura et al., 2016). In the present study, quantitative real-time PCR reveals that genes involved in heme biosynthesis and degradation were induced the spleen of in BKO mice. Interestingly, adulthood was associated with reduced splenic mRNA expression of these genes in WT mice whereas the mRNA levels in adult BKO mice were persistently increased. In accordance, mRNA levels of DMT1, which plays central role in erythroid iron transport across endosomes (Canonne-Hergaux et al., 2001), were also induced in adolescent and adult BKO mice. These findings indicate that extramedullary hematopoiesis in BKO mice was induced during both age groups. In accordance, histopathological examination also showed that the extent of extramedullary hematopoiesis in BKO mice was progressively increased with increasing age. Furthermore, the presence of anemia despite enhanced extramedullary erythropoiesis in BKO mice is indicative for ineffective erythropoiesis.

In this study, both tissue non-heme iron measurement and histopathological examination revealed progressive iron accumulation in the spleen of thalassemic mice particularly in adulthood. In contrast, liver iron deposition was not significantly altered between adolescent and adult BKO mice. Notably, Gardenghi et al. (Gardenghi et al., 2007) reported a differential pace of iron accumulation in BKO mice between the spleen and hepatic Kupffer cells. In accordance with our findings, the previous work by Kautz et al. (Kautz et al., 2015) demonstrated that iron content in the liver of BKO mice was markedly increased during early adolescence and reached plateau during late adolescence and early adulthood. The alteration in the pattern of tissue iron deposition between adolescence and adulthood suggests that systemic iron homeostasis could differ with age.

The expression of hepcidin, a systemic iron regulatory peptide, is regulated by several factors. Under thalassemic conditions, hepcidin might be concurrently affected by systemic iron loading, anemia and ineffective erythropoiesis. It has been proposed that although erythropoiesis, iron status, and inflammation all contribute to variation in hepcidin expression, 
328

329

330

331

332

333

334

335

336

337

338

339

340

341

342

343

344

345

346

347

348

349

350

351

352

353

354

355

356

357

358

with the work by Gardenghi et al. (Gardenghi et al., 2007), our data suggests that hepcidin expression is determined by both anemia and iron overload which have opposing effects. The net effect of these two factors on hepcidin expression, which may vary depending on age. In this study, the expression of Bmp6, a positive hepcidin regulator, and erythroid-secreted hepcidin suppressors (Erfe, Gdf15 and Twsg1) was induced in thalassemic mice. The lower hepcidin mRNA levels relative to liver non-heme iron contents in BKO mice suggest that hepcidin was influenced by erythroid regulators under thalassemic condition. On the contrary, liver hepcidin mRNA levels which reflect the net effects of hepcidin regulators did not differ between WT and BKO mice during adolescence. Therefore, we speculate that Bmp6 and erythroid regulators both contributed on hepcidin expression in adolescent thalassemic mice. In accordance with previous studies, we observed increased hepcidin expression in thalassemic mice during adulthood (Nai et al., 2012; Kumfu et al., 2016) compared to adolescence. However, the hepcidin-to-liver iron ratio in $\mathrm{BKO}$ mice did not alter between the two age groups suggesting that the increase in hepcidin mRNA levels was appropriate for the increase in liver iron contents. Additionally, we observed decreased splenic Erfe mRNA expression in adult BKO mice compared to adolescent counterpart. Interestingly, Erfe has recently been demonstrated to inhibit BMP6-induced hepcidin expression (Arezes et al., 2018). Accordingly, the relative reduction in Erfe mRNA expression in thalassemic mice during adulthood would allow hepcidin induction by BMP6 in response to increased liver iron accumulation. Notably, the previous study demonstrated that Erfe mRNA expression was consistently induced in the spleen of thalassemic mice during the age of 3 - 12 weeks (Kautz et al., 2015). A study to further explore whether Erfe mRNA levels in the spleen is altered in adult and aged thalassemic mice should be conducted.

We demonstrated that ferroportin mRNA expression in the spleen was induced in BKO mice and corresponded with the induction of genes involved in hemoglobin synthesis and degradation. Therefore, it is possible that increased erythropoiesis and subsequent degradation of erythroid cells are responsible for the increased splenic ferroportin expression in adult BKO mice. In agreement, erythrophagocytosis has been shown to induce ferroportin and HO-1 transcription in vitro (Knutson et al., 2003; Delaby et al., 2008). Furthermore, the expression of ferroportin in iron-recycling macrophages is upregulated by both heme and iron acquired from the degradation of hemoglobin in senescent red blood cells. Heme has been shown to transcriptionally induce ferroportin whereas the regulation of ferroportin expression by iron 
359

360

361

362

363

364

365

366

367

368

369

370

371

372

373

374

375

376

377

378

379

380

381

382

383

384

385

386

387

occurs at the translation level though IRP-IRE interaction (Marro et al., 2010; Drakesmith et al., 2015). In the liver, ferroportin mRNA expression was induced in adolescence and adult thalassemic mice, possibly, as a result of liver iron accumulation, which were present in both periods of lifespan. In line with our findings, iron dextran administration has been shown to induce liver ferroportin mRNA expression in $\mathrm{C} 3 \mathrm{HeB} / \mathrm{FeJ}$ mice (Liu et al., 2005). In contrast to ferroportin, we found that DMT1 mRNA expression in the liver was not affected by thalassemia or age. In thalassemia, the increase in iron levels in the circulation exceeds the binding capacity of apotransferrin resulting in the presence of non-transferrin bound iron (NTBI). Notably, previous study reported that DMT1 does not play an essential role in the uptake of NTBI in the liver (Wang \& Knutson, 2013). Further studies should be performed to delineate the roles of other NTBI transporters such as Zip14 in the pathophysiology of liver iron overload under thalassemic condition and to determine whether the expression of these transporters differs with age.

Intestinal iron hyperabsorption as a result of hepcidin downregulation has been previously reported in thalassemic mice (Gardenghi et al., 2007). In agreement, we demonstrated significant effects of thalassemia on the mRNA expression of apical iron transport machineries, Dcytb and DMT1, in the duodenum. Interestingly, reduced Dcytb and DMT1 mRNA expression was observed in the duodenum of adult WT and BKO mice compared to adolescent counterparts. These changes in duodenal iron transporter expression also coincided with the reduction in serum iron levels of both WT and BKO mice during adulthood. It has previously been shown that hepcidin expression inversely correlates with duodenal iron transporters mRNA expression and iron absorption in rats (Frazer et al., 2002; Frazer et al., 2004; Millard et al., 2004). However, our study observed Dcytb and DMT1 downregulation in adult WT mice compared to adolescent WT mice although hepcidin expression was unaltered between these two age groups. Therefore, we speculate that hepcidin did not directly involve in the altered Dcytb and DMT1 expression between adolescence and adulthood. Previous study in rat reported that the expression of Dcytb, DMT1 and ferroportin was significantly affected by age (Kong et al., 2015). Moreover, hypoxia-inducible factor 2 alpha (HIF-2 $\alpha$ ) has been shown to transcriptionally induce Dcytb and DMT1 in response to iron deficiency (Mastrogiannaki et al., 2009; Shah et al., 2009). In the present study, we not only found anemia in BKO mice but also reduced levels of RBC count, hemoglobin and hematocrit in adolescent WT mice compared 
390

391

392

393

394

395

396

397

398

399

400

401

402

403

404

405

406

\section{Conclusions}

408

409

410

411

412

413

414

415

416

417

418

419

420

adult WT mice. It is therefore possible that anemia-associated hypoxia was responsible for the upregulation of intestinal iron transporters observed in our adolescent mice. The mechanisms of age-associated changes in duodenal iron transporters including the possible roles of HIF-2 $\alpha$ remain to be elucidated.

In summary, our study demonstrated that several hematological and iron homeostatic parameters were different between adolescence and adulthood. As the mice progressed from adolescence to adulthood, duodenal iron transporter mRNA expression and serum iron levels of both WT and BKO mice were decreased. Reduced splenic expression of genes involved in hemoglobin metabolism as well as alteration in erythrocyte parameters were found only in WT mice. In BKO mice, erythrocyte abnormalities along with induction of genes involved in hemoglobin metabolism in the spleen were persistent in both adolescence and adulthood. Interestingly, adulthood was associated with increased liver hepcidin and ferroportin mRNA expression along with splenic Erfe mRNA suppression only in BKO mice. The limitations of the present study include the lack of findings on serum hepcidin and Erfe levels as well as gene expression in the bone marrow. In addition, the expression of iron transporters at the protein level should be performed in future studies.

Our study demonstrated that iron homeostasis in a mouse model of thalassemia intermedia differed between adolescence and adulthood. During adolescence, increased mRNA expression of duodenal iron transporters was associated with liver iron accumulation. In adult BKO mice, the induction of splenic Erfe and duodenal iron transporters was diminished compared to adolescent BKO mice. Furthermore, extramedullary erythropoiesis is enhanced and the spleen becomes preferential site of tissue iron loading. The present study demonstrates that iron homeostasis in thalassemia intermedia might be altered with age per se and disease progression. The present study underscores the significance of age on the expression of genes involved in iron metabolism as well as the pathophysiology of iron loading in thalassemia intermedia. Therefore, the age of thalassemic mice should be considered in the study of iron homeostasis under thalassemic condition

\section{Acknowledgements}


421 We would like to thank Thalassemia Research Center, Institute of Molecular Biosciences,

422 Mahidol University for supplying thalassemic mice.

423

424

425

Additional information and declarations

426

Funding

427

This work is supported by Office of the Higher Education Commission, The Thailand Research

428

Fund, Mahidol University, Siriraj Research Fund, Faculty of Medicine Siriraj Hospital, Mahidol

429

University, National Research Council of Thailand (NRCT). C.S. was supported by the Royal

430

Golden Jubilee (RGJ) scholarship from The Thailand Research Fund (PHD/0052/2556) and

431

National Research University (NRU) scholarship, Thailand.

432

433

\section{Competing Interests}

434 The authors declare that they have no competing interests.

435

436

437

438

439

440

441

442

443

444

445

446

447

448

449

450

\section{References}

Abboud S, Haile DJ. 2000. A novel mammalian iron-regulated protein involved in intracellular iron metabolism. J Biol Chem 275(26):19906-19912 DOI 10.1074/jbc.M000713200.

Ahluwalia N, Gordon MA, Handte G, Mahlon M, Li NQ, Beard JL, Weinstock D, Ross AC. 2000. Iron Status and Stores Decline with Age in Lewis Rats. J Nutr 130(9):2378-2383 DOI 10.1093/jn/130.9.2378.

Amigo JD, Yu M, Troadec MB, Gwynn B, Cooney JD, Lambert AJ, Chi NC, Weiss MJ, Peters LL, Kaplan J, Cantor AB, Paw BH. 2011. Identification of distal cis-regulatory elements at mouse mitoferrin loci using zebrafish transgenesis. Mol Cell Biol 31(7):13441356 DOI 10.1128/MCB.01010-10.

Andriopoulos B Jr, Corradini E, Xia Y, Faasse SA, Chen S, Grgurevic L, Knutson MD, Pietrangelo A, Vukicevic S, Lin HY, Babitt JL. 2009. BMP6 is a key endogenous regulator of hepcidin expression and iron metabolism. Nat Genet 41(4):482-487 DOI 10.1038/ng.335. 
451

452

453

454

455

456

457

458

459

460

461

462

463

464

465

466

467

468

469

470

471

472

473

474

475

476

477

478

479

480

Arezes J, Foy N, McHugh K, Sawant A, Quinkert D, Terraube V, Brinth A, Tam M, LaVallie ER, Taylor S, Armitage AE, Pasricha SR, Cunningham O, Lambert M, Draper SJ, Jasuja R, Drakesmith H. 2018. Erythroferrone inhibits the induction of hepcidin by BMP6. Blood 132(14):1473-1477 DOI 10.1182/blood-2018-06-857995.

Barton JC, Edwards CQ, Bertoli LF, Shroyer TW, Hudson SL. 1995. Iron overload in African Americans. Am J Med 99(6):616-623.

Bannerman RM. 1983. Hematology in the mouse in biomedical research. In: Foster HL, Small JD, Fox JG, eds. The mouse in biomedical research: normative biology, husbandry, and models. San Diego: Academic Press, 293-312.

Beard JL. 2000. Iron Requirements in Adolescent Females. J Nutr 130(2):440S-442S DOI $10.1093 / \mathrm{jn} / 130.2 .440 \mathrm{~S}$.

Canonne-Hergaux F, Zhang AS, Ponka P, Gros P. 2001. Characterization of the iron transporter DMT1 (NRAMP2/DCT1) in red blood cells of normal and anemic mk/mk mice. Blood 98(13):3823-3830 DOI 10.1182/blood.v98.13.3823.

Capecchi MR. 2005. Gene targeting in mice: functional analysis of the mammalian genome for the twenty-first century. Nat Rev Genet 6(6):507-512.

Chen H, Attieh ZK, Gao H, Huang G, Su T, Ke W, Vulpe CD. 2009. Age-related changes in iron homeostasis in mouse ferroxidase mutants. Biometals 22(5):827-834 DOI 10.1007/s10534-009-9229-0.

Chiabrando D, Mercurio S, Tolosano E. 2014. Heme and erythropoieis: more than a structural role. Haematologica 99(6):973-983 DOI 10.3324/haematol.2013.091991.

Courselaud B, Troadec MB, Fruchon S, Ilyin G, Borot N, Leroyer P, Coppin H, Brissot P, Roth MP, Loréal O. 2004. Strain and gender modulate hepatic hepcidin 1 and 2 mRNA expression in mice. Blood Cells Mol Dis 32(2):283-289.

Cox TC, Bawden MJ, Martin A, May BK. 1991. Human erythroid 5-aminolevulinate synthase: promoter analysis and identification of an iron-responsive element in the mRNA. The EMBO journal 10(7):1891-1902.

Dandekar T, Stripecke R, Gray NK, Goossen B, Constable A, Johansson HE, Hentze MW. 1991. Identification of a novel iron-responsive element in murine and human erythroid delta-aminolevulinic acid synthase mRNA. The EMBO journal 10(7):1903-1909.

Peer] reviewing PDF | (2019:07:39544:2:0:NEW 4 Feb 2020) 
481

482

483

484

485

486

487

488

489

490

491

492

493

494

495

496

497

498

499

500

501

502

503

504

505

506

507

508

509

510

511

De Franceschi L, Daraio F, Filippini A, Carturan S, Muchitsch EM, Roetto A, Camaschella C. 2006. Liver expression of hepcidin and other iron genes in two mouse models of betathalassemia. Haematologica 91(10):1336-1342.

Delaby C, Pilard N, Puy H, Canonne-Hergaux F. 2008. Sequential regulation of ferroportin expression after erythrophagocytosis in murine macrophages: early mRNA induction by haem, followed by iron-dependent protein expression. Biochem J 411(1):123-131.

Detloff PJ, Lewis J, John SW, Shehee WR, Langenbach R, Maeda N, Smithies O. 1994. Deletion and replacement of the mouse adult beta-globin genes by a "plug and socket" repeated targeting strategy. Mol Cell Biol 14(10):6936-6943.

Donovan A, Brownlie A, Zhou Y, Shepard J, Pratt SJ, Moynihan J, Paw BH, Drejer A, Barut B, Zapata A, Law TC, Brugnara C, Lux SE, Pinkus GS, Pinkus JL, Kingsley PD, Palis J, Fleming MD, Andrews NC, Zon LI. 2000. Positional cloning of zebrafish ferroportin1 identifies a conserved vertebrate iron exporter. Nature 403 (6771): 776-781 DOI $10.1038 / 35001596$.

Drakesmith H, Nemeth E, Ganz T. 2015. Ironing out Ferroportin. Cell metabolism 22(5):777787 DOI 10.1016/j.cmet.2015.09.006.

Everds N. 2007. Hematology of the laboratory mouse. In: Fox J, editor. The mouse in biomedical research. Waltham (MA): Academic Press, 135-163.

Flurkey K, Currer JM, Harrison DE. 2007. Mouse models in aging research. In: Fox JG, Barthod SW, Davisson MT, Newcomer CE, Quimby FW, Smith AL, eds. The mouse in biomedical research, 2nd. Amsterdam: Academic Press, 637-672.

Foy AL, Williams HL, Cortell S, Conrad ME. 1967. A modified procedure for the determination of nonheme iron in tissue. Anal Biochem 18(3):559-563 DOI 10.1016/0003-2697(67)90113-3.

Frazer DM, Inglis HR, Wilkins SJ, Millard KN, Steele TM, McLaren GD, McKie AT, Vulpe CD, Anderson GJ. 2004. Delayed hepcidin response explains the lag period in iron absorption following a stimulus to increase erythropoiesis. Gut 53(10):1509-1515.

Frazer DM, Wilkins SJ, Becker EM, Vulpe CD, McKie AT, Trinder D, Anderson GJ. 2002. Hepcidin expression inversely correlates with the expression of duodenal iron transporters and iron absorption in rats. Gastroenterology 123(3):835-844 DOI 10.1053/gast.2002.35353. 
512 Gammella E, Buratti P, Cairo G, Recalcati S. 2017. The transferrin receptor: the cellular iron

513

514

515

516

517

518

519

520

521

522

523

524

525

526

527

528

529

530

531

532

533

534

535

536

537

538

539

540

541 gate. Metallomics 9(10):1367-1375 DOI 10.1039/c7mt00143f.

Gardenghi S, Marongiu MF, Ramos P, Guy E, Breda L, Chadburn A, Liu Y, Amariglio N, Rechavi G, Rachmilewitz EA, Breuer W, Cabantchik ZI, Wrighting DM, Andrews NC, de Sousa M, Giardina PJ, Grady RW, Rivella S. 2007. Ineffective erythropoiesis in beta-thalassemia is characterized by increased iron absorption mediated by downregulation of hepcidin and up-regulation of ferroportin. Blood 109(11):5027-5035.

Gelderman MP, Baek JH, Yalamanoglu A, Puglia M, Vallelian F, Burla B, Vostal J, Schaer DJ, Buehler PW. 2015. Reversal of hemochromatosis by apotransferrin in nontransfused and transfused Hbbth3/+ (heterozygous B1/B2 globin gene deletion) mice. Haematologica 100(5):611-622 DOI 10.3324/haematol.2014.117325.

Gunshin H, Mackenzie B, Berger UV, Gunshin Y, Romero MF, Boron WF, Nussberger S, Gollan JL, Hediger MA. 1997. Cloning and characterization of a mammalian protoncoupled metal-ion transporter. Nature 388 (6641):482-488 DOI 10.1038/41343.

Hahn P, Song Y, Ying GS, He X, Beard J, Dunaief JL. 2009. Age-dependent and genderspecific changes in mouse tissue iron by strain. Exp Gerontol 44(9):594-600 DOI 10.1016/j.exger.2009.06.006.

Hentze MW, Muckenthaler MU, Andrews NC. 2004. Balancing acts: molecular control of mammalian iron metabolism. Cell 117(3):285-297.

Higgs DR, Engel JD, Stamatoyannopoulos G. 2012. Thalassaemia. Lancet 379(9813):373-383 DOI 10.1016/S0140-6736(11)60283-3.

Hubert N, Hentze MW. 2002. Previously uncharacterized isoforms of divalent metal transporter (DMT)-1: implications for regulation and cellular function. Proc Natl Acad Sci US A 99(19):12345-12350.

Jamsai D, Zaibak F, Khongnium W, Vadolas J, Voullaire L, Fowler KJ, Gazeas S, Fucharoen S, Williamson R, Ioannou PA. 2005. A humanized mouse model for a common beta0-thalassemia mutation. Genomics 85(4):453-461.

Jandl JH, Inman JK, Simmons RL, Allen DW. 1959. Transfer of iron from serum ironbinding protein to human reticulocytes. J Clin Invest 38(1):161-185 DOI 10.1172/JCI103786. 
542 Karafin MS, Koch KL, Rankin AB, Nischik D, Rahhal G, Simpson P, Field JJ. 2015.

543 Erythropoietic drive is the strongest predictor of hepcidin level in adults with sickle cell

544 disease. Blood Cells Mol Dis 55(4):304-307 DOI 10.1016/j.bcmd.2015.07.010.

545 Kautz L, Jung G, Du X, Gabayan V, Chapman J, Nasoff M, Nemeth E, Ganz T. 2015.

546 Erythroferrone contributes to hepcidin suppression and iron overload in a mouse model

547 of beta-thalassemia. Blood 126(17):2031-2037 DOI 10.1182/blood-2015-07-658419.

548 Kautz L, Jung G, Valore EV, Rivella S, Nemeth E, Ganz T. 2014. Identification of

549 erythroferrone as an erythroid regulator of iron metabolism. Nat Genet 46(7):678-684

$550 \quad$ DOI $10.1038 /$ ng.2996.

551 Knutson MD, Vafa MR, Haile DJ, Wessling-Resnick M. 2003. Iron loading and

552 erythrophagocytosis increase ferroportin 1 (FPN1) expression in J774 macrophages.

553 Blood 102(12):4191-4197.

554 Koeller DM, Casey JL, Hentze MW, Gerhardt EM, Chan LN, Klausner RD, Harford JB.

555

556

557

558

559

560

561

562

563

1989. A cytosolic protein binds to structural elements within the iron regulatory region of the transferrin receptor mRNA. Proc Natl Acad Sci U S A 86(10):3574-3578 DOI:10.1073/pnas.86.10.3574.

Kong WN, Gao G, Chang YZ. 2014. Hepcidin and sports anemia. Cell Biosci 4:19 DOI 10.1186/2045-3701-4-19.

Kong WN, Wu Q, Shen D, Zhao SE, Guo P, Duan XL, Chang YZ. 2015. Age-dependent expression of duodenal cytochrome $b$, divalent metal transporter 1 , ferroportin 1 , and hephaestin in the duodenum of rats. J Gastroenterol Hepatolol 30(3):513-520 DOI

564

565

566 10.1111/jgh.12830.

Krijt J, Cmejla R, Sýkora V, Vokurka M, Vyoral D, Necas E. 2004. Different expression pattern of hepcidin genes in the liver and pancreas of C57BL/6N and DBA/2N mice. $J$ Hepatol 40(6):891-896.

567

568

569

Kumfu S, Chattipakorn SC, Fucharoen S, Chattipakorn N. 2016. Effects of iron overload condition on liver toxicity and hepcidin/ferroportin expression in thalassemic mice. Life Sci 150:15-23 DOI 10.1016/j.1fs.2016.02.082.

570

Lane DJ, Merlot AM, Huang ML, Bae DH, Jansson PJ, Sahni S, Kalinowski DS, 571 Richardson DR. 2015. Cellular iron uptake, trafficking and metabolism: Key molecules 
572

573

574

575

576

577

578

579

580

581

582

583

584

585

586

587

588

589

590

591

592

593

594

595

596

597

598

599

600

601

602

and mechanisms and their roles in disease. Biochim Biophys Acta 1853(5):1130-1144 DOI 10.1016/j.bbamcr.2015.01.021.

Laviola G, Macri S, Morley-Fletcher S, Adriani W. 2003. Risk-taking behavior in adolescent mice: psychobiological determinants and early epigenetic influence. Neurosci Biobehav Rev 27:19-31.

Lesbordes-Brion JC, Viatte L, Bennoun M, Lou DQ, Ramey G, Houbron C, Hamard G, Kahn A, Vaulont S. 2006. Targeted disruption of the hepcidin 1 gene results in severe hemochromatosis. Blood 108(4):1402-1405 DOI.10.1182/blood-2006-02-003376.

Li H, Choesang T, Bao W, Chen H, Feola M, Garcia-Santos D, Li J, Sun S, Follenzi A, Pham P, Liu J, Zhang J, Ponka P, An X, Mohandas N, Fleming RE, Rivella S, Li G, Ginzburg YZ. 2017. Decreasing TfR1 expression reverses anemia and hepcidin suppression in beta-thalassemic mice. Blood 129(11):1514-1526 DOI 10.1182/blood2016-09-742387.

Liu XB, Nguyen NB, Marquess KD, Yang F, Haile DJ. 2005. Regulation of hepcidin and ferroportin expression by lipopolysaccharide in splenic macrophages. Blood Cells Mol Dis 35(1):47-56 DOI 10.1016/j.bcmd.2005.04.006.

Livak KJ, Schmittgen TD. 2001. Analysis of relative gene expression data using real-time quantitative PCR and the 2(-Delta Delta C(T)) Method 25(4):402-408.

Marro S, Chiabrando D, Messana E, Stolte J, Turco E, Tolosano E, Muckenthaler MU. 2010. Heme controls ferroportin1 (FPN1) transcription involving Bach1, Nrf2 and a MARE/ARE sequence motif at position -7007 of the FPN1 promoter. Haematologica 95(8):1261-1268 DOI 10.3324/haematol.2009.020123.

Mastrogiannaki M, Matak P, Keith B, Simon MC, Vaulont S, Peyssonnaux C. 2009. HIF2alpha, but not HIF-1alpha, promotes iron absorption in mice. J Clin Invest 119(5):11591166 DOI 10.1172/JCI38499.

McKie AT, Barrow D, Latunde-Dada GO, Rolfs A, Sager G, Mudaly E, Mudaly M, Richardson C, Barlow D, Bomford A, Peters TJ, Raja KB, Shirali S, Hediger MA, Farzaneh F, Simpson RJ. 2001. An iron-regulated ferric reductase associated with the absorption of dietary iron. Science 291(5509):1755-1759 DOI:10.1126/science.1057206.

McKie AT, Marciani P, Rolfs A, Brennan K, Wehr K, Barrow D, Miret S, Bomford A, Peters TJ, Farzaneh F, Hediger MA, Hentze MW, Simpson RJ. 2000. A novel 
603

604

605

606

607

608

609

610

611

612

613

614

615

616

617

618

619

620

621

622

623

624

625

626

627

628

629

630

631

632

duodenal iron-regulated transporter, IREG1, implicated in the basolateral transfer of iron to the circulation. Mol Cell 5 (2):299-309.

McLachlan S, Page KE, Lee SM, Loguinov A, Valore E, Hui ST, Jung G, Zhou J, Lusis AJ, Fuqua B, Ganz T, Nemeth E, Vulpe CD. 2017. Hampl mRNA and plasma hepcidin levels are influenced by sex and strain but do not predict tissue iron levels in inbred mice. Am J Physiol Gastrointest Liver Physiol 313(5):G511-G23 DOI 10.1152/ajpgi.00307.2016.

Millard KN, Frazer DM, Wilkins SJ, Anderson GJ. 2004. Changes in the expression of intestinal iron transport and hepatic regulatory molecules explain the enhanced iron absorption associated with pregnancy in the rat. Gut 53(5):655-660.

Nai A, Pagani A, Mandelli G, Lidonnici MR, Silvestri L, Ferrari G, Camaschella C. 2012. Deletion of TMPRSS6 attenuates the phenotype in a mouse model of beta-thalassemia. Blood 119(21):5021-5029 DOI 10.1182/blood-2012-01-401885.

Nemeth E, Tuttle MS, Powelson J, Vaughn MB, Donovan A, Ward DM, Ganz T, Kaplan J. 2004. Hepcidin regulates cellular iron efflux by binding to ferroportin and inducing its internalization. Science 306(5704):2090-2093.

Nicolas G, Chauvet C, Viatte L, Danan JL, Bigard X, Devaux I, Beaumont C, Kahn A, Vaulont S. 2002a. The gene encoding the iron regulatory peptide hepcidin is regulated by anemia, hypoxia, and inflammation. J Clin Invest 110(7):1037-1044.

Nicolas G, Viatte L, Bennoun M, Beaumont C, Kahn A, Vaulont S. 2002b. Hepcidin, a new iron regulatory peptide. Blood Cells Mol Dis 29(3):327-335.

Paradkar PN, Zumbrennen KB, Paw BH, Ward DM, Kaplan J. 2009. Regulation of Mitochondrial Iron Import through Differential Turnover of Mitoferrin 1 and Mitoferrin 2. Mol Cell Biol 29(4):1007-1016 DOI 10.1128/MCB.01685-08.

Pigeon C, Ilyin G, Courselaud B, Leroyer P, Turlin B, Brissot P, Loréal O. 2001. A new mouse liver-specific gene, encoding a protein homologous to human antimicrobial peptide hepcidin, is overexpressed during iron overload. J Biol Chem 276(11):7811-7819.

Pollycove M, Mortimer R. 1961. The quantitative determination of iron kinetics and hemoglobin synthesis in human subjects. J Clin Invest 40:753-782 DOI 10.1172/JCI104310. 
633 Shah YM, Matsubara T, Ito S, Yim SH, Gonzalez FJ. 2009. Intestinal hypoxia-inducible

634

635

636

637

638

639

640

641

642

643

644

645

646

647

648

649

650

651

652

653

654

655

656

657

658

659

660

661

662

663 transcription factors are essential for iron absorption following iron deficiency. Cell Metab 9(2):152-164 DOI 10.1016/j.cmet.2008.12.012.

Shaw GC, Cope JJ, Li L, Corson K, Hersey C, Ackermann GE, Gwynn B, Lambert AJ, Wingert RA, Traver D, Trede NS, Barut BA, Zhou Y, Minet E, Donovan A, Brownlie A, Balzan R, Weiss MJ, Peters LL, Kaplan J, Zon LI, Paw BH. 2006. Mitoferrin is essential for erythroid iron assimilation. Nature 440(7080):96-100.

Simpson RJ, Peters TJ. 1990. Forms of soluble iron in mouse stomach and duodenal lumen: significance for mucosal uptake. Br J Nutr 63(1):79-89 DOI 10.1079/bjn19900093.

Tanimura N, Miller E, Igarashi K, Yang D, Burstyn JN, Dewey CN, Bresnick EH. 2016. Mechanism governing heme synthesis reveals a GATA factor/heme circuit that controls differentiation. EMBO Rep 17(2):249-265 DOI 10.15252/embr.201541465.

Tanno T, Bhanu NV, Oneal PA, Goh SH, Staker P, Lee YT, Moroney JW, Reed CH, Luban NL, Wang RH, Eling TE, Childs R, Ganz T, Leitman SF, Fucharoen S, Miller JL. 2007. High levels of GDF15 in thalassemia suppress expression of the iron regulatory protein hepcidin. Nat Med 13(9):1096-1101.

Tanno T, Porayette P, Sripichai O, Noh SJ, Byrnes C, Bhupatiraju A, Lee YT, Goodnough JB, Harandi O, Ganz T, Paulson RF, Miller JL. 2009. Identification of TWSG1 as a second novel erythroid regulator of hepcidin expression in murine and human cells. Blood 114(1):181-186 DOI 10.1182/blood-2008-12-195503.

Upanan S, Pangjit K, Uthaipibull C, Fucharoen F, McKie AT, Srichairatanakool S. 2015. Combined treatment of 3-hydroxypyridine-4-one derivatives and green tea extract to induce hepcidin expression in iron-overloaded $\beta$-thalassemic mice. Asian Pac J Trop Biomed 5(12):1010-1017.

Vogiatzi MG, Tsay J, Verdelis K, Rivella S, Grady RW, Doty S, Giardina PJ, Boskey AL. 2010. Changes in bone microarchitecture and biomechanical properties in the th 3 thalassemia mouse are associated with decreased bone turnover and occur during the period of bone accrual. Calcif Tissue Int 86(6):484-494 DOI 10.1007/s00223-010-9365-0.

Vulpe CD, Kuo YM, Murphy TL, Cowley L, Askwith C, Libina N, Gitschier J, Anderson GJ .1999. Hephaestin, a ceruloplasmin homologue implicated in intestinal iron transport, is defective in the sla mouse. Nat Genet 21 (2):195-199. DOI 10.1038/5979. 
664 Wallace DF. 2016. The Regulation of Iron Absorption and Homeostasis. Clin Biochem Rev $665 \quad 37(2): 51-62$.

666 Wang CY, Knutson MD. 2013. Hepatocyte divalent metal-ion transporter-1 is dispensable for

667

668

669

670

671

672

673

674

675

676

677

678

679

680

681

682

683

684

685

686

687

688

689

690

691

692

693

694 hepatic iron accumulation and non-transferrin-bound iron uptake in mice. Hepatology 58(2):788-798 DOI 10.1002/hep.26401.

Wannasuphaphol B, Kalpravidh R, Pattanapanyasat K, Ioannau P, Kuypers FA, Fucharoen S, Winichagoon P. 2005. Rescued mice with Hb E transgene-developed red cell changes similar to human beta-thalassemia/HbE disease. Ann New Y Acad Sci 1054:407-416 DOI 10.1196/annals.1345.049.

Weatherall DJ, Clegg JB. 2001. The pathophysiology of the thalassaemias. The thalassemia syndromes, 4th edition. London: Blackwell Science, 192-236.

Weizer-Stern O, Adamsky K, Amariglio N, Rachmilewitz E, Breda L, Rivella S, Rechavi G. 2006. mRNA expression of iron regulatory genes in beta-thalassemia intermedia and beta-thalassemia major mouse models. Am J Hematol 81(7):479-483.

Yang B, Kirby S, Lewis J, Detloff PJ, Maeda N, Smithies O. 1995. A mouse model for beta 0thalassemia. Proc Natl Acad Sci U S A 92(25):11608-11612.

Yatmark P, Morales NP, Chaisri U, Wichaiyo S, Hemstapat W, Srichairatanakool S, Svasti S, Fucharoen S. 2014. Iron distribution and histopathological characterization of the liver and heart of beta-thalassemic mice with parenteral iron overload: Effects of deferoxamine and deferiprone. Exp Toxicol Pathol 66(7):333-343 DOI 10.1016/j.etp.2014.03.002.

\section{Figures legends}

Figure 1 Perl's Prussian blue staining of tissue samples from WT and BKO mice at adolescence and adulthood. Perl's Prussian blue staining was performed in representative paraffin-embedded tissue sections from the liver (A-D), spleen (E-H) and duodenum (I-L) of male WT and BKO mice aged 6-7 weeks and 16-20 weeks. The blue stain represents iron accumulation. The arrows indicate iron accumulation in the supranuclear region of enterocytes. (Nikon ECLIPSE 80i light microscope ; magnification x400) 
695 Figure 2 Hematoxylin and eosin staining of tissue samples from WT and BKO mice at 696 adolescence and adulthood. Hematoxylin and eosin staining of representative paraffin697 embedded tissue sections from the liver (A-D), spleen (E-H) and duodenum (I-L) of male WT 698 and BKO mice aged 6-7 weeks and 16-20 weeks. The arrows indicate mononuclear cells and 699 hematopoietic cells in the liver and spleen. (Nikon ECLIPSE 80i light microscope ; 700 magnification $\mathrm{x} 400)$

701

702

Figure 3 The expression of genes involved in hemoglobin biosynthesis and degradation in 703 the spleen of WT and BKO mice at adolescence and adulthood. Quantitative RT-PCR of

704 TfR1 (A), Mfrn1 (B), ALAS2 (C) and HO-1 (D) mRNA from the spleen of WT and BKO mice aged 6-7 weeks and 16-20 weeks. Values are presented as means and SEM for minus delta Ct

706 values ( $\mathrm{n}=5$ per group). Statistical analysis was performed by 2-way ANOVA with Bonferroni 707 post-hoc test.

708

709

Figure 4 The expression of hepcidin and upstream regulators of hepcidin in WT and BKO

710 mice at adolescence and adulthood. Quantitative RT-PCR of (A) hepatic hepcidin (B) hepatic hepcidin/ iron content (C) hepatic Bmp6 and (D-F) upstream erythroid regulators of hepcidin (Gdf15, Twsg1, Erfe) in the spleen of WT and BKO mice aged 6-7 weeks and 16-20 weeks. Values are presented as means and SEM for minus delta $\mathrm{Ct}$ values $(\mathrm{n}=5$ per group). Statistical analysis was performed by 2-way ANOVA with Bonferroni post-hoc test.

715

Figure 5 The expression of major iron transporters in the liver and spleen of WT and BKO mice at adolescence and adulthood. Quantitative RT-PCR of (A) hepatic DMT1 (B) hepatic ferroportin (C) splenic DMT1 and (D) splenic ferroportin of WT and BKO mice aged 6-7 weeks and 16-20 weeks. Values are presented as means and SEM for minus delta $\mathrm{Ct}$ values $(\mathrm{n}=5$ per group). Statistical analysis was performed by 2-way ANOVA with Bonferroni post-hoc test. mice at adolescence and adulthood. Quantitative RT-PCR of of (A) duodenal Dcytb (B) duodenal DMT1 and (C) duodenal ferroportin of WT and BKO mice aged 6-7 weeks and 16-20 
725 weeks. Values are presented as means and SEM for minus delta $\mathrm{Ct}$ values ( $\mathrm{n}=5$ per group).

726 Statistical analysis was performed by 2-way ANOVA with Bonferroni post-hoc test. 
Figure 1

Figure 1 Perl's Prussian blue staining of representative paraffin-embedded tissue sections from the liver, spleen and duodenum of male WT and BKO mice aged 6-7 weeks and 16-20 weeks

The blue stain represents iron accumulation. The arrows indicate iron accumulation in brush border of enterocytes. (Nikon ECLIPSE 80i light microscope ; magnification x400) 

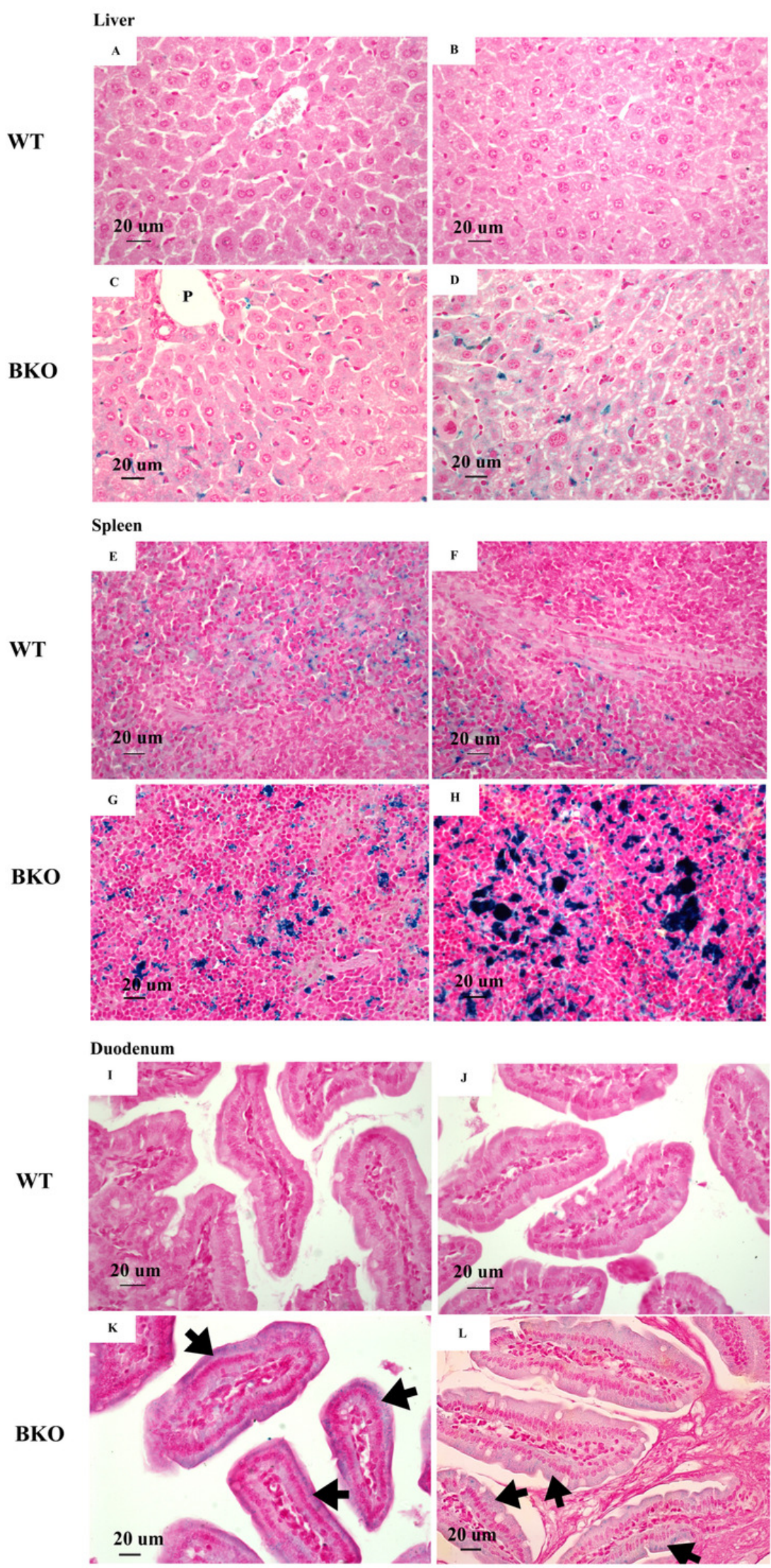
Figure 2

Figure 2 Hematoxylin and eosin staining of representative paraffin-embedded tissue sections from the liver, spleen and duodenum of male WT and BKO mice aged 6-7 weeks and 16-20 weeks

The arrows indicate mononuclear cells and hematopoietic cells in the liver and spleen. (Nikon ECLIPSE 80i light microscope ; magnification x400) 

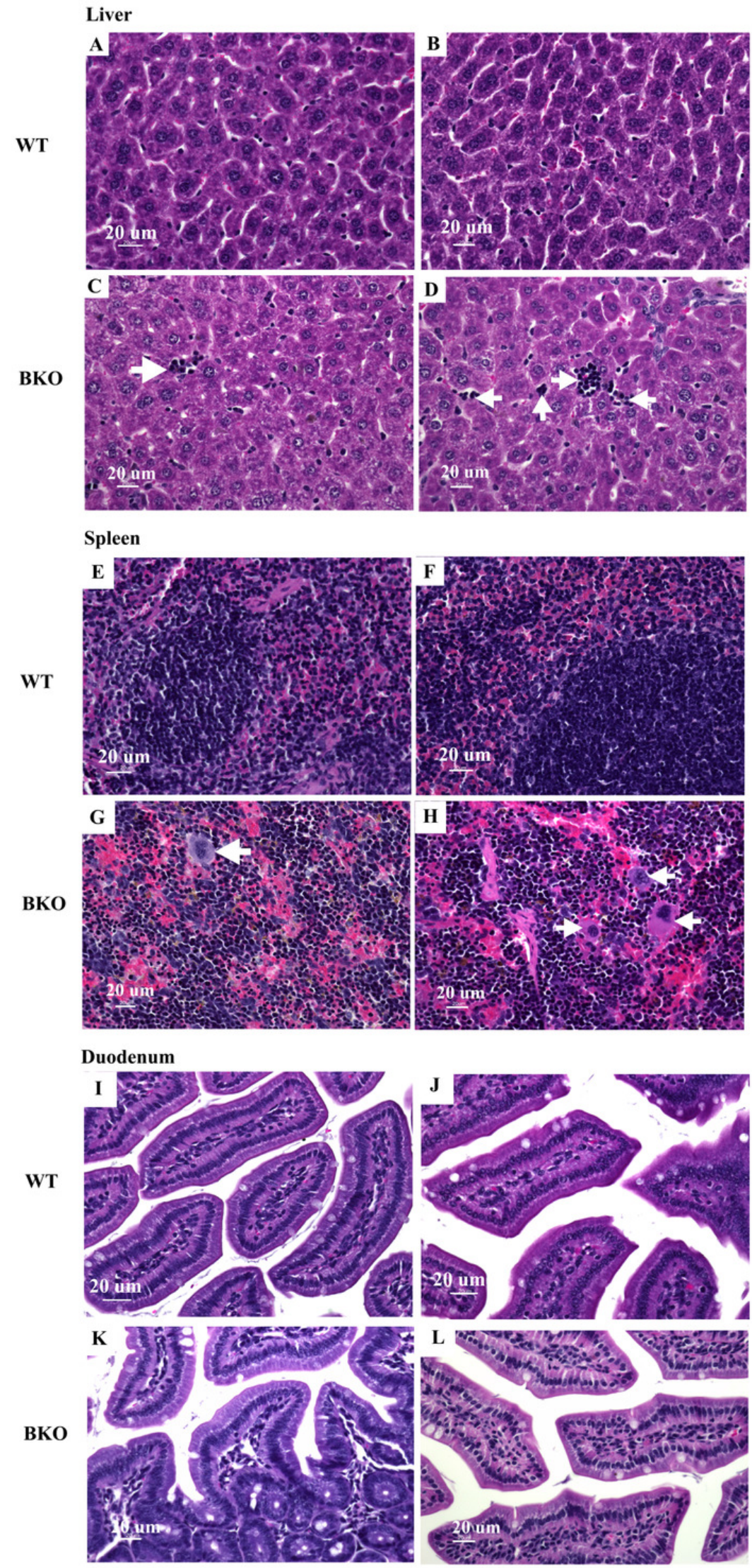


\section{Figure 3}

Figure 3 The expression of genes involved in hemoglobin biosynthesis and degradation in the spleen of wild type and thalassemic mice

Quantitative RT-PCR of Tfrc (TfR1), Slc25a37 (Mfrn1), Alas2 (ALAS2) and Hmox1 (HO-1) mRNA from the spleen of WT and BKO mice aged 6-7 weeks and 16-20 weeks. Relative mRNA expression was acquired by normalizing to Actb ( $\beta$-actin) mRNA. Values are presented as means and SEM for minus delta Ct values ( $\mathrm{n}=$ 5 per group). Statistical analysis was performed by 2-way ANOVA with Bonferroni post-hoc test. $P$-values for the effects of phenotype, age and interaction are shown in the figure. Statistical significance for pairwise comparison is indicated by $*$ symbols $(* * P<0.01, * * * P<0.001)$

(A)

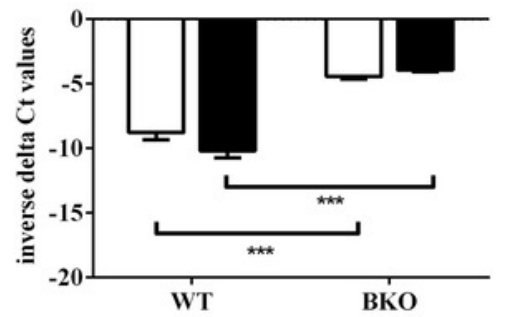

(C)

Spleen ALAS2

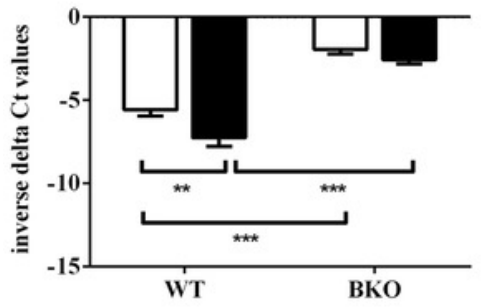

๑6-7 weeks 16-20 weeks

ANOVA P value: Interaction: $\quad 0.0305$

Phenotype: $<0.0001$

Age: $\quad 0.2797$

ANOVA P value:

Interaction: $\quad 0.1619$

Phenotype: $<0.0001$

Age: $\quad 0.0063$

口 6-7 weeks 16-20 weeks
(B)

Spleen Mfrn1

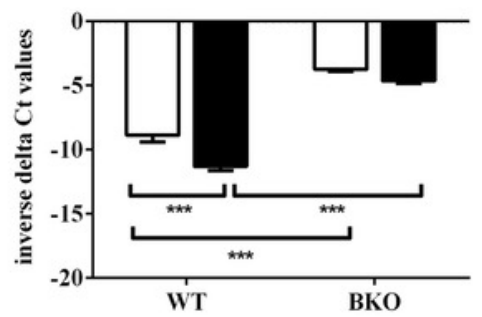

ANOVA P value:

Interaction: $\quad 0.0367$

Phenotype: $<0.0001$

Age: $\quad 0.0001$

6-7 weeks 16-20 weeks

(D)

Spleen HO-1

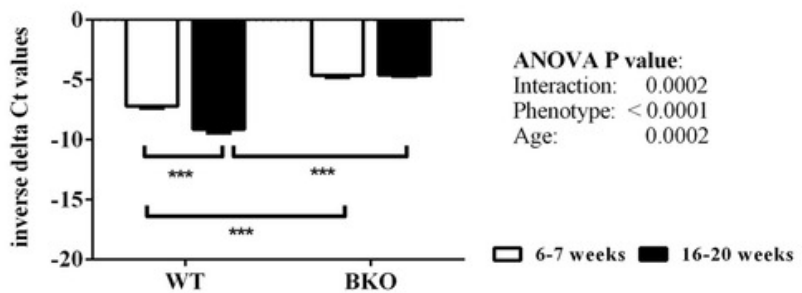




\section{Figure 4}

Figure 4 The expression of hepcidin and upstream regulators of hepcidin in wild type and thalassemic mice

Quantitative RT-PCR of (A) Hamp (hepcidin) mRNA in the liver (B) Liver hepcidin mRNA relative to liver iron content (C) Bmp6 mRNA in the liver (D-F) upstream regulators of hepcidin (Gdf15, Twsg1, Fam132b) mRNA in the spleen of WT and BKO mice aged 6-7 weeks and 16-20 weeks. Relative mRNA expression was acquired by normalizing to Actb ( $\beta$-actin) mRNA. Values are presented as means and SEM for minus delta Ct values ( $n=5$ per group). Statistical analysis was performed by 2-way ANOVA with Bonferroni post-hoc test. $P$-values for the effects of phenotype, age and interaction are shown in the figure. Statistical significance for pairwise comparison is indicated by $*$ symbols $(* P<0.05, * * P<0.01, * * * P<0.001)$

(A)

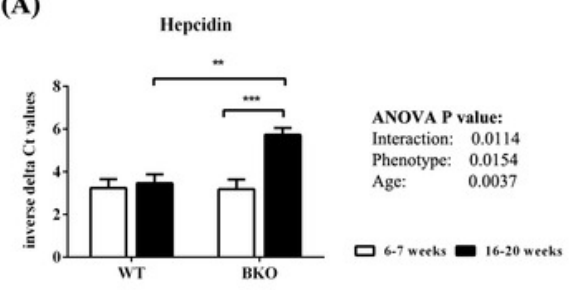

(D)

Spleen Gdf15

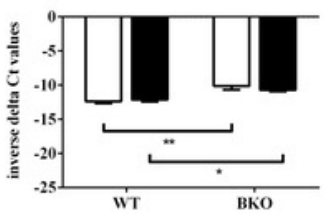

ANOVA P value:
Interaction: 0.2953 $\begin{array}{ll}\text { Interaction: } & 0.2953 \\ \text { Phenotype: } & 0.0001\end{array}$ \begin{tabular}{ll} 
Age: & 0.6382 \\
Agentype: & 0.0001 \\
\hline
\end{tabular} 口 6.7 weeks $16-20$ weeks
(B)

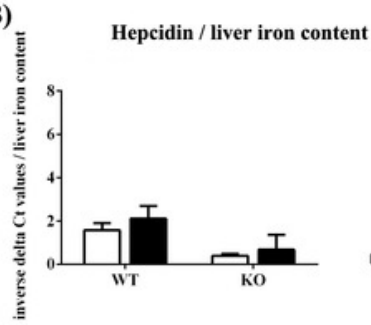

(E)

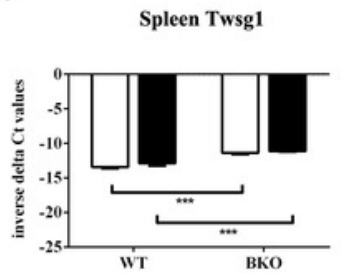

(C)

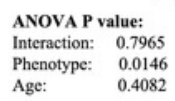

口6.7 weeks 16.20 weeks

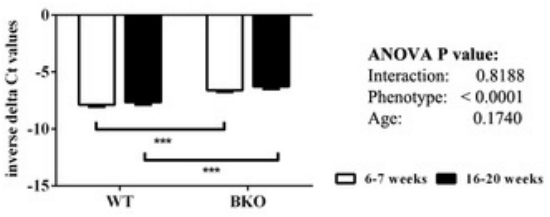

(F)

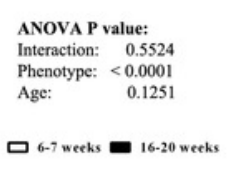

Liver Bmp6

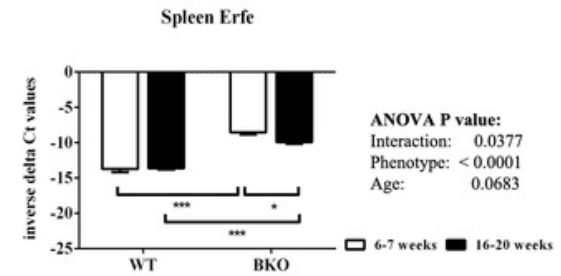




\section{Figure 5}

Figure 5 The expression of major liver and spleen iron transporters in wild type and thalassemic mice

Quantitative RT-PCR of (A) Liver Slc11a2 (DMT1) mRNA, (B) Liver Slc40a1 (ferroportin) mRNA (C) Spleen Slc11a2 (DMT1) mRNA (D) Spleen Slc40a1 (ferroportin) mRNA of WT and BKO mice aged 6-7 weeks and 16-20 weeks. Relative mRNA expression was acquired by normalizing to Actb ( $\beta$-actin) mRNA. Values are presented as means and SEM for minus delta Ct values ( $n=5$ per group). Statistical analysis was performed by 2-way ANOVA with Bonferroni post-hoc test. $P$-values for the effects of phenotype, age and interaction are shown in the figure. Statistical significance for pairwise comparison is indicated by $*$ symbols (**P < $0.01, * * * P<0.001)$

(A)

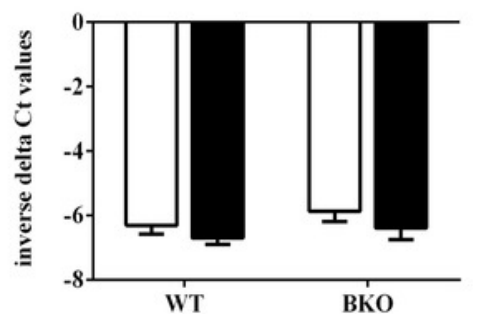

(C)

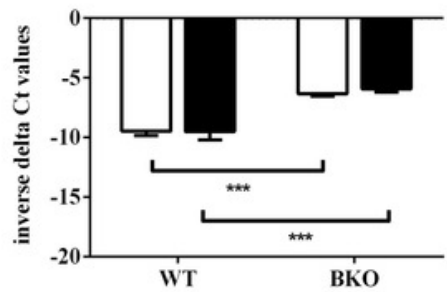

(B)

Liver ferroportin

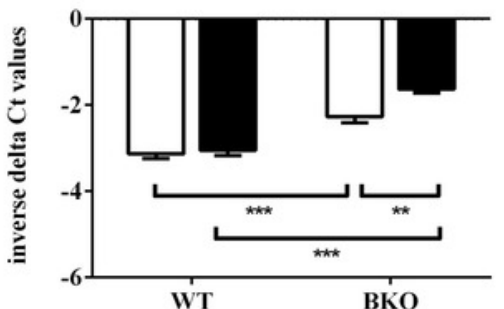

$\square$ 6-7 weeks 16-20 weeks

ANOVA P value: Interaction: $\quad 0.0286$ Phenotype: $<0.0001$ Age: $\quad 0.0070$

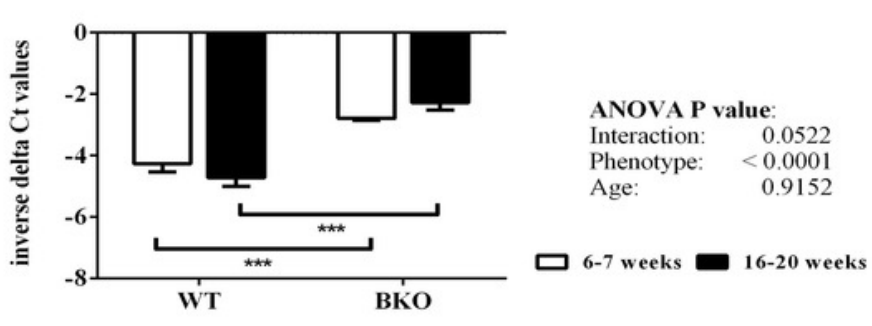

(D)

\section{Spleen ferroportin}

Interaction: $\quad 0.8398$

$\begin{array}{ll}\text { Phenotype: } & 0.2115 \\ \text { Age: } & 0.1347\end{array}$

ロ 6-7 weeks 16-20 weeks

ANOVA P value:

$\begin{array}{ll}\text { Interaction: } & 0.6179 \\ \text { Phenotype: } & <0.0001\end{array}$

Phenotype: $\quad<0.0001$
Age: $\quad 0.6843$

ロ 6-7 weeks $16-20$ weeks 


\section{Figure 6}

Figure 6 The expression of major duodenal iron transport machineries in wild type and thalassemic mice

Quantitative RT-PCR of (A) Cybrd1 (Dcytb) (B) Slc11a2 (DMT1) (C) Slc40a1 (ferroportin) mRNA from the duodenum of WT and BKO mice aged 6-7 weeks and 16-20 weeks. Relative mRNA expression was acquired by normalizing to Actb ( $\beta$-actin) mRNA. Values are presented as means and SEM for minus delta Ct values (n $=5$ per group). Statistical analysis was performed by 2-way ANOVA with Bonferroni post-hoc test. $P$-values for the effects of phenotype, age and interaction are shown in the figure. Statistical significance for pairwise comparison is indicated by $*$ symbols $(* P<0.05, * * P<0.01, * * * P<0.001)$ 
(A) Duodenum Dcytb

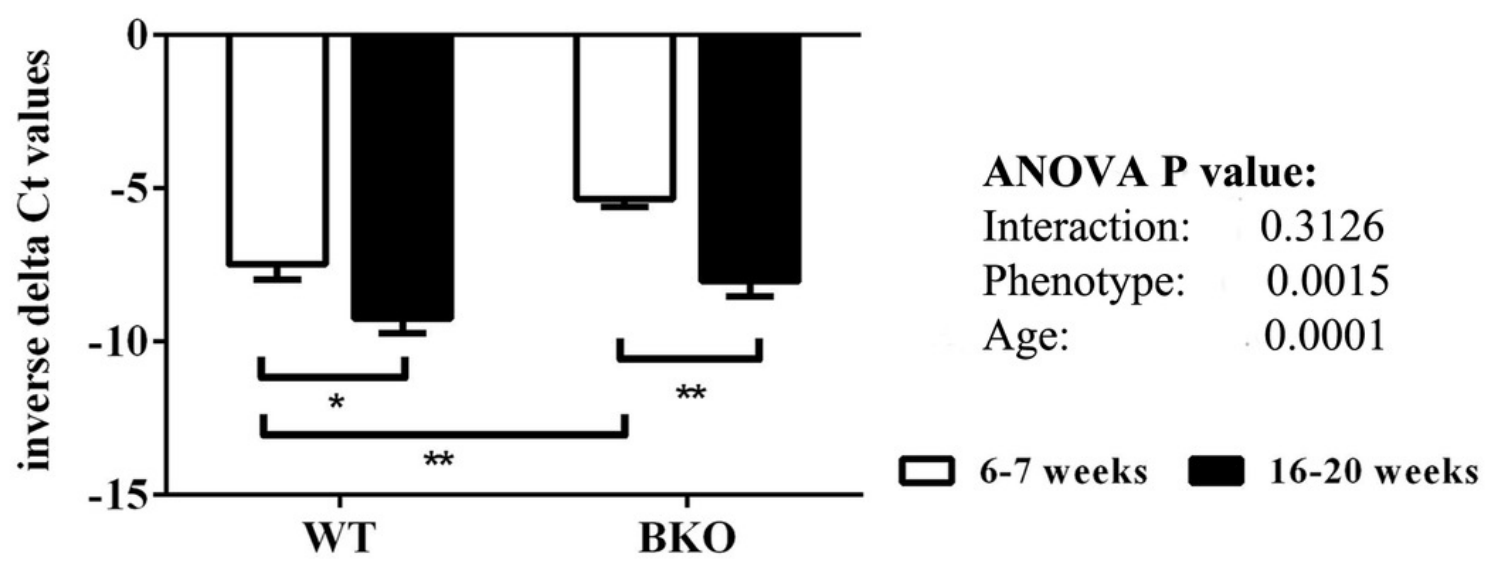

(B)

Duodenum DMT1

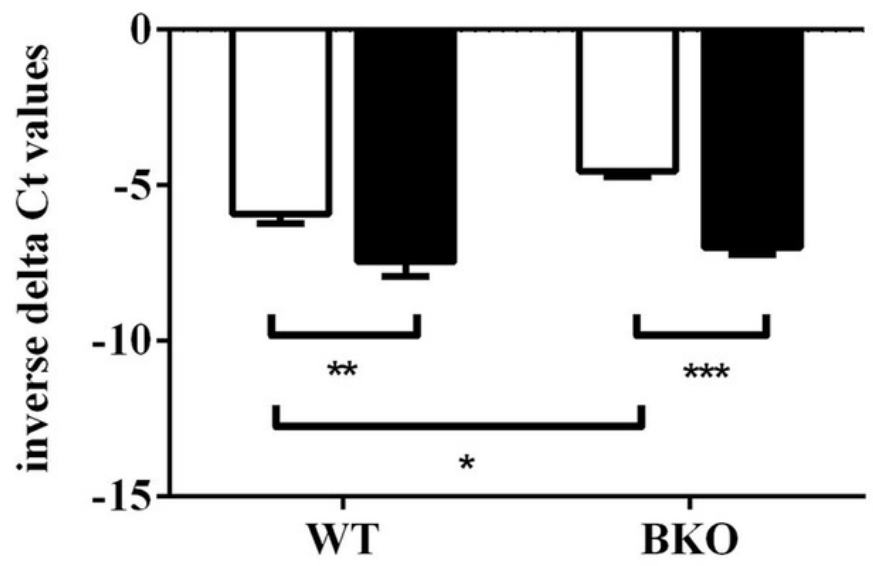

ANOVA P value:

Interaction: $\quad 0.1659$

Phenotype: 0.0094

Age: $\quad<0.0001$

(C)

Duodenum ferroportin

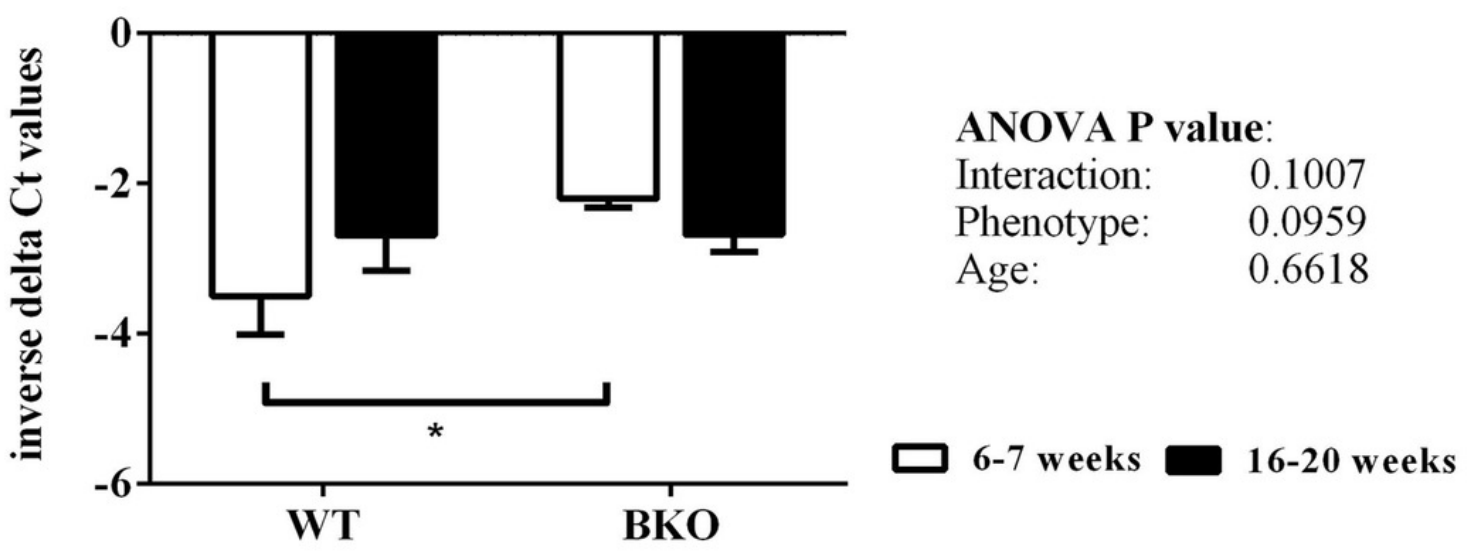




\section{Table 1 (on next page)}

Sequence of gene-specific primers 


\begin{tabular}{|c|c|c|}
\hline Gene product & Forward primer & Reverse primer \\
\hline$A c t b(\beta$-actin $)$ & CAGCCTTCCTTCTTGGGTA & TTTACGGATGTCAACGTCACAC \\
\hline Alas2 (ALAS2) & AGCCATTGTCCTTTCATGCT & CAGCAGGTCTGTCTTGAAAGTCT \\
\hline Bmp6 (Bmp6) & GCCAACTACTGTGATGGAGAGTGTT & CTCGGGATTCATAAGGTGGACCA \\
\hline Cybrd1 (Dcytb) & TTTGTCCTGAAACACCCCTC & AGAAGGCCCAGCGTATTTGT \\
\hline Fam132b (Erfe) & TCCTCTATCTACAGGCAGGAC & ACTGCGTACCGTGAGGGA \\
\hline Gdf15 (Gdf15) & GAGCTACGGGGTCGCTTC & GGGACCCCAATCTCACCT \\
\hline Hamp (Hepcidin) & CAGGGCAGACATTGCGATAC & GTGGCTCTAGGCTATGTTTTGC \\
\hline Hmoxl (HO-1) & CAGAGCCGTCTCGAGCATAG & CAAATCCTGGGGCATGCTGT \\
\hline Slc1la2 (DMT1) & TTCTACTTGGGTTGGCAGTGTT & CAGCAGGACTTTCGAGATGC \\
\hline Slc25a37 (Mfrn1) & ACGCCATGTATTTTGCCTGC & ACTCCCAGCTACCCCATTAG \\
\hline Slc40al (ferroportin) & ATCCCCATAGTCTCTGTCAGC & CAGCAACTGTGTCACCGTCA \\
\hline Tfrc (TfR1) & TCCTTTCCTTGCATATTCTGG & CCAAATAAGGATAGTCTGCATCC \\
\hline Twsg1 (Twsg1) & GCTGTCACACCATGAAAACCTAG & ACTGTGCACATGCGCTCTT \\
\hline
\end{tabular}

1 


\section{Table 2 (on next page)}

Hematological data and iron parameters of male wild type and thalassemic mice at the age of 6-7 weeks and 16-20 weeks 


\section{Table 2 Hematological data and iron status in various ages of male WT and BKO mice.}

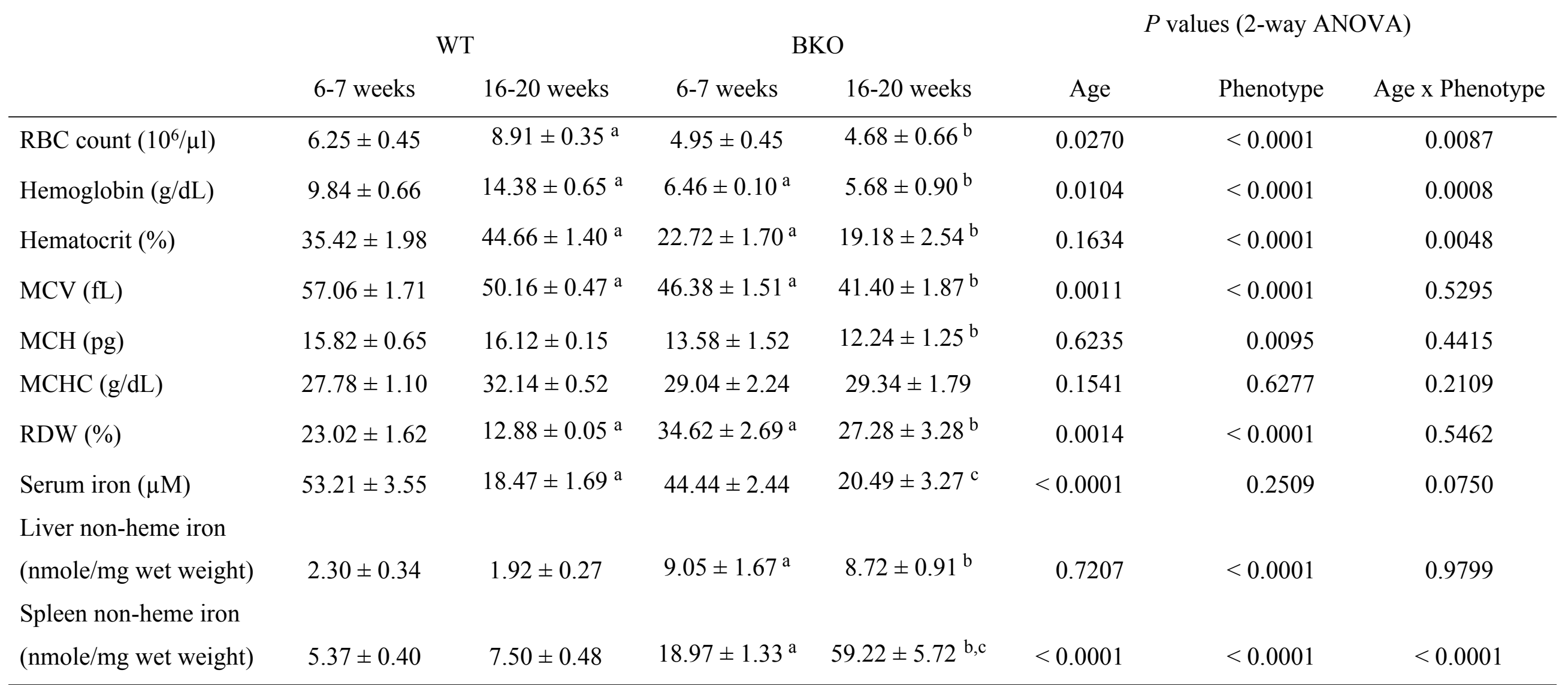

Notes.

RBE, red blood cell; MCV, mean corpuscular volume; $\mathrm{MCH}$, mean corpuscular hemoglobin; MCHC, mean corpuscular hemoglobin con«entration; RDW, red cell distribution width. 
Dat5 expressed as mean \pm SEM ( $n=5$ /group). Statistical analysis was performed by 2-way ANOVA with Bonferroni post-hoc test. a, b6: $P$-value $<0.05$ compared with WT aged 6-7 weeks and 16-20 weeks, respectively. $\sigma: P$-value $<0.05$ compared with $\mathrm{BKO}$ aged 6-7 weeks. 


\section{Table 3(on next page)}

Iron deposition score in the liver, spleen and duodenum of male wild type and thalassemic mice at the age of 6-7 weeks and 16-20 weeks 
1

Table 3 Iron deposition score in the liver, spleen and duodenum of WT and BKO mice at adolescence (6-7 weeks old) and adulthood (16-20 weeks old).

Age

Iron deposition score

\begin{tabular}{lccc}
\multicolumn{1}{c}{ Age } & Liver & Spleen & Duodenum \\
\hline WT & 0 & 1 & 0 \\
$6-7$ weeks & 0 & 1 & 0 \\
$16-20$ weeks & 1 & 1 \\
BKO & 1 & 2 \\
$6-7$ weeks & 3 & 1 \\
$16-20$ weeks & & \\
\hline 2 & & \\
3 & The same deposition score was obtained from the mouse within same group (n $=5$ per group).
\end{tabular}




\section{Table 4 (on next page)}

Mononuclear cells infiltration and hematopoietic cells score in the liver of male wild type and thalassemic mice at the age of 6-7 weeks and 16-20 weeks 
Table 4 Mononuclear cells infiltration and hematopoietic cells score in the liver of male WT and thalassemic mice at different age ranges.

$P$ values (2-way ANOVA)

\begin{tabular}{|c|c|c|c|c|c|c|c|}
\hline & \multicolumn{2}{|c|}{ WT } & \multicolumn{2}{|c|}{$\mathrm{BKO}$} & \multirow[b]{2}{*}{ Age } & \multirow[b]{2}{*}{ Phenotype } & \multirow[b]{2}{*}{ Age x Phenotype } \\
\hline & 6-7 weeks & 16-20 weeks & 6-7 weeks & 16-20 weeks & & & \\
\hline Mononuclear cells & & & & & & & \\
\hline $\begin{array}{l}\text { and hematopoietic } \\
\text { cells score }\end{array}$ & $0.12 \pm 0.02$ & $0.16 \pm 0.14$ & $1.86 \pm 0.08^{\mathrm{a}}$ & $2.92 \pm 0.15^{\mathrm{b}, \mathrm{c}}$ & 0.0001 & $<0.0001$ & 0.0003 \\
\hline
\end{tabular}

1

2 Notes.

3 Data expressed as mean \pm SEM ( $\mathrm{n}=5$ /group). Statistical analysis was performed by 2-way ANOVA with Bonferroni post-hoc test.

4 a, b : $P$-value $<0.05$ compared with WT aged 6-7 weeks and 16-20 weeks, respectively.

$5 \quad \mathrm{c}: P$-value $<0.05$ compared with $\mathrm{BKO}$ aged 6-7 weeks 